\title{
Examination of the Relationship Between Creative Thinking Skills and Comprehension Skills of Middle School Students
}

\author{
Emine SUR* \\ Ministry of Education, Konya, Turkey \\ ORCID: 0000-0002- 6594-8885
}

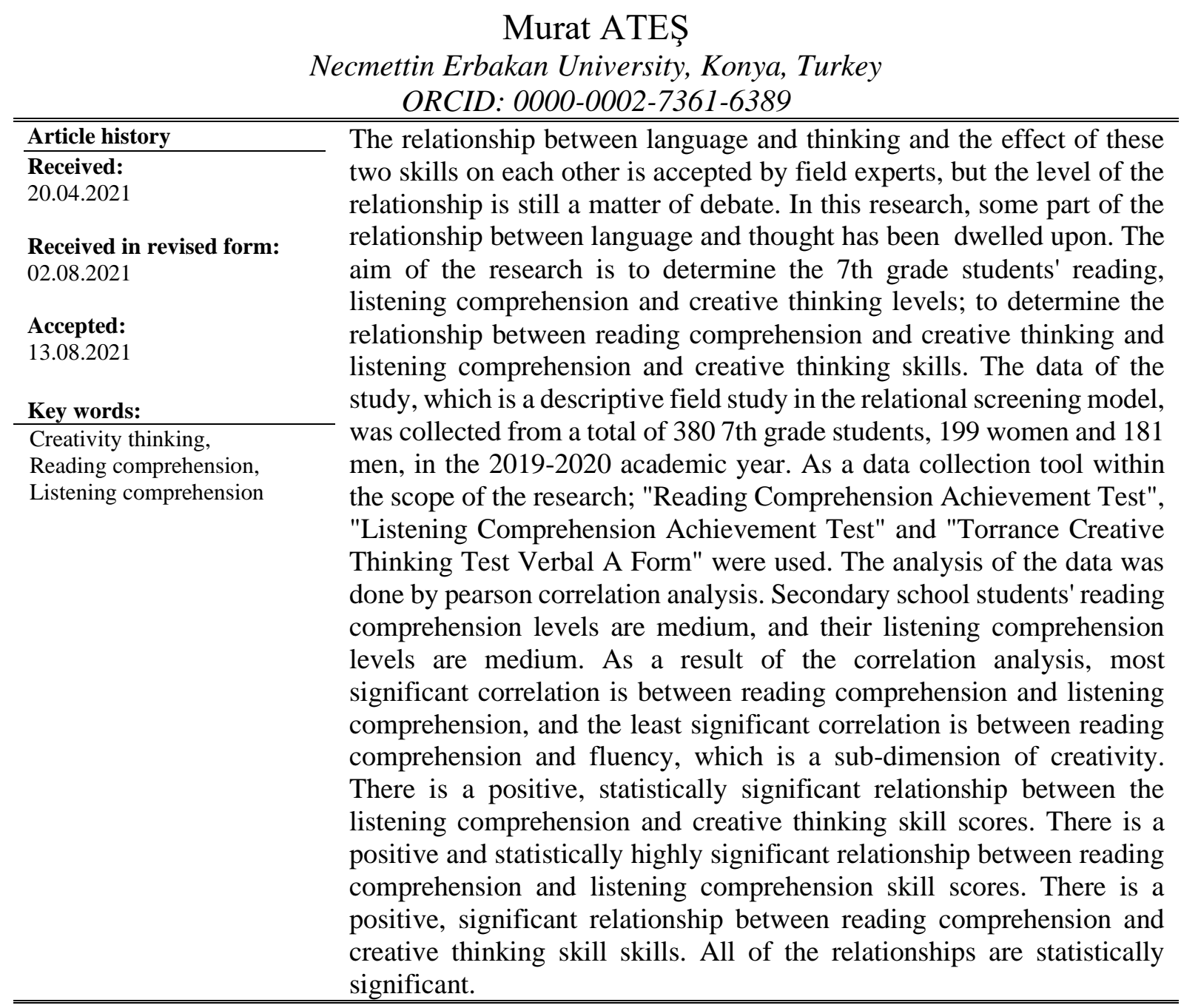

\footnotetext{
*Correspondency: eminesur30@ @gmail.com
} 


\section{Introduction}

Rising the standard of living rapidly, human beings have changed the world significantly thanks to the remarkable inventions in science and technology and created a new world order that is much more complex than before. The emerging new order has not only changed and facilitated personal, social, and economic life considerably, but also brought many difficulties. The dramatic increase in unqualified knowledge, the continuous orientation of the masses by means of purposeful messages such as advertising, the fact that artificial communication environment pushes people to anti-social life (Söylemez, 2016, p. 372), and problems such as epidemics, economic crisis and natural disasters that have a devastating effect on societies from time to time are among these difficulties. Individuals' adaptation to the changes in the 21 st century and their ability to overcome the difficulties they encounter in this process depends on having a series of cognitive skills and competencies. Acquiring skills and competencies required by modern society will enable individuals to both complete their own development and serve the progress of society of which they are a part.

Thinking and creating original products and new ideas are among the basic skills that distinguish human beings from other living things and have moved them to where they are now. Today's creativity has largely emerged through the work of Torrance and Guilford. In his speech as the Chairman of the American Psychological Association, Guilford (1950, p. 445) emphasized the importance of creativity and called for doing research, which led to the revival of creativity studies. Creativity has been widely addressed by different disciplines in recent years because it is an area of interest for individuals, societies and organizations (Wallas, 1926; Seidel et al., 2010, p. 14). According to Fisher and Williams $(2004$, p. 8$)$ the fact that creativity includes dimensions of person, process and product has caused field researchers to make different definitions on this subject. Gardner (1997, p. 145) highlights the product dimension of creativity and defines it as a problem-solving ability from which new products emerge. Rogers (1961), Maslow (1973), and May (1976) emphasize the person dimension of the creative process and explain creativity as the expression of the inner being, self-actualization, understanding life, coping with disharmony and tension, and directing self toward the new (Cropley, 2006, p. 3). Ülgen (1995; as cited in Çam \& Öztürk Turgut, 2015, p. 80) emphasizes the multidimensional thinking process of creativity and describes creativity as a multidimensional thinking process where new and useful products are produced, the patterns formed through following different paths from the main routes, and the information is taken and shaped until a new thought is created. Creativity emerges as a result of the interaction of these three dimensions. Knowledge lies at the basis of creative thinking, which contributes to the production of new solutions to the problems encountered and plays an important role in the world taking today's form. The most effective and practical way to reach information is through the effective use of reading and listening skills.

Comprehension is the ability to perceive what a text or speech means, to comprehend what is seen or heard. Listening, another dimension of comprehension, is a language skill that starts with hearing and transmitting sound stimuli exceeding 20 decibels to the brain, continues with making sense of what is heard by using mental processes such as perception, interpretation, evaluation, and ends with shaping behaviors when necessary (Demirel \& Şahinel, 2006; Temur, 2010; p. 72; Ungan, 2007, p. 149). Reading, on the other hand, refers to accessing words via the eye movement on lines, perception through sense organs, understanding their meanings, vocalizing, participating in a communicative activity, interpreting, and reacting when necessary (Davarc1, 2013, p. 1; Öz, 2011, p. 193). Reading is a process in which different senses are involved and all kinds of written symbols are perceived, understood, and interpreted. Reading is a mental activity resulting from the interaction between the reader and the writer, starts with 
the perception of written symbols, continues with the use of many strategies such as interpretation, criticism, attention, analysis, synthesis, and reflects the communicative interaction between the author's intention, the content of the message, and the reader's purpose.

\section{Related research}

When the literature is examined, it is seen that a number of studies have been carried out on reading, listening, creative and critical thinking skills.

Ünal (2012) investigated the relationship between 5th grade students' critical reading levels, their attitudes towards reading and their reading comprehension levels, and determined the degree of the relationship. At the end of the study, it was seen that the students' reading comprehension levels were not sufficient, there was a high level of significant relationship between their reading attitudes and critical reading skills, and a moderately significant relationship between their reading comprehension levels and critical reading skills.

Ateş (2008), in his study, aimed to determine the relationship between the reading comprehension levels of primary school secondary school students, their attitudes towards the Turkish lesson and their academic achievements. At the end of the research, gender's attitude, understanding and academic achievement; Income level was found to be a significant variable affecting attitude and general academic achievement. In addition, in the research, there is a low positive relationship between the scores of attitude towards Turkish lesson, reading comprehension level, academic success in Turkish lesson and general academic achievement; It was concluded that there is a positive and high relationship between reading comprehension and Turkish course success and academic success average.

Girgin (2012), in his research, aimed to determine the effect of concept maps on students' reading comprehension level and permanence. As a result of the research, the pre-test, post-test and retention test success averages of the experimental group in which the concept maps method was applied were higher than the control group.

Çelebi (2008), evaluated the listening skills of 6th, 7th, 8th grade primary school students according to the writings of events and thoughts; It has been concluded that the students' level of listening and understanding the thought writings is at a moderate level.

In the study of Bulut (2013), the effect of the active listening training given to the fourth-grade students on the students' listening comprehension, reading comprehension and vocabulary was examined. As a result of the pre-test applied to the experimental and control groups, it was seen that the students' listening comprehension scores were at a moderate level. At the end of the research, it was seen that active listening education contributed positively to the development of fourth grade students' listening comprehension, reading comprehension and vocabulary levels.

In his research Hizır (2014), examined whether the individual's creative thinking, creative products and solutions develop skills through creative reading activities. At the end of the research, it was concluded that creative reading practice affected students' creative thinking skills positively.

Wojciehowski \& Ernst (2018) examined the effect of preschool nature experience on the development of creative thinking in young children. It was concluded that nature significantly increased the creative thinking scores of preschool children. 


\section{Importance of Research}

Reading and listening skills, which form the comprehension dimension of the language, express a complex process, and cannot be observed in the outside world, which seems from the fact that language is a thought-driven process. Thinking is an important ability that is unique to humans and distinguishes humans from other living things. It should be emphasized that without language, it is possible to think and produce thoughts without using language. However, it is possible to say that language develops and concretizes thought and gives it functionality (Gül \& Soysal, 2009). This shows that there is a relationship between language and thinking. When the literature is examined, no research has been found that determines the relationship between language and thinking.

This study identifies some of the relationship between language and thought. It aims to determine middle school 7th grade students' reading comprehension, listening comprehension and creative thinking levels and the relationship between comprehension skills and creative thinking skills. The main research question of the study is "Is there a relationship between the creative thinking skills of the students and their comprehension skills?" Based on the basic research question, the sub-problems are determined as follows:

(1) How are the reading and listening comprehension skills levels of the 7th grade students?

(2) How are the creative thinking skill levels of 7 th grade students?

(3) Is there a significant relationship between the creative thinking skills of 7 th grade students and their reading and listening comprehension skills?

\section{Method}

This study, prepared to examine the relationship between creative thinking skills of middle school students and their comprehension skills, is a descriptive field study that used the survey model. Survey models are research approaches that aim to describe a past or present situation the way as it exists (Karasar, 2019, p. 109).

\section{Study Sample}

The sample of the study consisted of 380 7th grade students studying at eight different state schools in the Konya province of Turkey in the 2019-2020 academic year. When students enter the abstract operational period (11-15 years old), they begin to gain new gains on top of their gains in the concrete operational period, and this makes it possible for the adolescent to reach a higher level of balance (Ahioğlu-Lindberg, 2011). The 7th grade is a period in which the abstract processing period is entered, and higher-order thinking skills are developed. For this reason, the study group was selected from 7 th grade students. The sample was drawn from the schools located in the central districts of Konya using the simple random sampling method. In this sampling method, all units have an equal and independent chance to be included in the sample (Büyüköztürk et al., 2013, p. 85). Of the participants $52.36 \%(\mathrm{n}=199)$ were female and $47.63 \%(\mathrm{n}=181)$ were male.

\section{Data Collection Tools}

The study data were collected using the Reading Comprehension Achievement Test (RCAT) to assess students' reading comprehension skills, the Listening Comprehension Achievement Test (LCAT) for listening comprehension skills, and the Torrance Tests of Creative Thinking (TTCT) for creative thinking skills. Reading and listening comprehension tests were developed by the researcher. 


\section{Reading Comprehension Achievement Test}

In the first step of the study, the texts to be used in the reading comprehension test were selected. For this, first of all, Turkish textbooks taught in secondary school 7 th grades both in the previous years and in the 2018-2019 academic year were determined and the texts in the textbooks were read several times by the researcher in detail. Five informative, five narrative, and five poem texts were selected from the aforementioned books for the reading comprehension achievement test. The selected texts were presented to a children's literature expert, two field experts and an assessment and evaluation expert, and they were asked to evaluate. A total of 60 items, including at least two questions, were prepared for the achievements in the Turkish Lesson Curriculum related to the texts determined in line with the expert opinions. After the items were written, expert opinion was taken; Four items were removed from the test and seven items were rearranged. The application was made on 150 students. An item analysis of the reading comprehension achievement test was conducted, and the discrimination index of fourteen items was found to be below 0.30 . For this reason, fourteen items were removed from the test and the analysis was repeated. The item difficulty index of the reading comprehension achievement test was 0.547 and the item discrimination index was 0.475 . Based on these results, it is possible to say that the items measure the property to be measured with the test, that is, they are valid.

\section{Listening Comprehension Achievement Test}

In the first step of the study, the texts to be used in the listening comprehension test were selected. For this, first of all, Turkish textbooks taught in secondary school 7th grades both in the previous years and in the 2018-2019 academic year were determined and the listening texts in the textbooks were read several times by the researcher in detail. Two informative, two narrator and two poem texts were selected for the achievement test of listening comprehension from the books in question. The selected texts were presented to a children's literature expert, two field experts and an assessment and evaluation expert, and they were asked to evaluate. A total of 30 items, including at least two questions, were prepared for the achievements in the Turkish Language Curriculum related to the texts determined in line with the expert opinions. After the items were written, expert opinion was taken; Three items were removed from the test, and five items were rearranged. As a result of the item analysis on the listening comprehension achievement test, it was observed that the discrimination index of three items remained below 0.30 . Therefore, three items were removed from the test and the analysis was repeated. The mean item difficulty index of the test was 0.582 and the mean item discrimination index was 0.517 . Based on these results, it is possible to say that the items measure the property to be measured with the test, that is, they are valid.

\section{Torrance Creative Thinking Test}

The test battery developed in 1966 consists of "verbal" and "figural" parts. The test consists of a total of 10 subtests, seven subtests in the verbal part and three subtests in the figural part. The subtests in the verbal part consist of asking questions, guessing causes, predicting results, product development, unusual uses, unusual questions, suppose activities. In the figural part, respectively; There are subtests named picture creation, picture completion, parallel lines. Verbal and formal tests are answered depending on the time. (Aslan, 2001).

\section{Cornell Critical Thinking Test Level X}

Cornell Critical Thinking Tests consist of two separate measurement tools, Level X and Level Z. Level X, 4th-14th. to classes, it is a measurement tool suitable for Level Z talented 
secondary school students, undergraduate and higher groups. In this study, Cornell Critical Thinking Test Level $\mathrm{X}$ was used as the relationship between the critical thinking skills and comprehension skills of secondary school students will be examined. CEDTDX, developed by Ennis and Millman (1985), is a widely used test to measure critical thinking skills at primary school level, with the effect of being multiple choice, prepared in story style, and easy to calculate all over the world (Akar, 2007). The test consists of four dimensions: making inferences by inductive reasoning, making inferences through deductive reasoning, judging the reliability of observations and sources, and identifying (determining) assumptions in statements. The dimension-whole test correlation values of the test were calculated as 0.71 for the inductive dimension, 0.69 for the dimension of judging the reliability of the claims, 0.84 for the deduction dimension, and 0.55 for the recognizing assumptions dimension. Item discrimination 4-8. It was found between 0.36 and 0.64 in 6 studies conducted at grade level (Ennis et al., 2005; cited in Akar, 2007: 54).

During the application of the test, it was deemed appropriate to allocate twenty-five minutes for the first two sections and fifteen minutes for the last two sections for the seventh graders. The test was administered in a total of 80 minutes. The tests used in this study were obtained from Palindrom Science Culture Education and Research Institution, which is the legal owner of the test in Turkey. Scoring tables of the test were received from the same institution with excel.

\section{Data Collection}

The data of the research were collected in October-March in the 2019-2020 academic year. The data collection tools used in the research were applied for 6 lesson hours in the schools in the study group. At which lesson time the application will be made in schools is determined in line with the request of the administration. In the applications, "Listening Comprehension Achievement Test", "Reading Comprehension Achievement Test" and "Torrance Creative Thinking Test", "Cornell Critical Thinking Test Level X" and "Personal Information Form" were applied. All applications were carried out by the researcher. When there was a written week in the research process, the data collection process was disrupted, and this situation was compensated with the applications made the next week. During the research, a total of 126 lesson hours were used in 21 different seventh grade branches of 8 schools.

\section{Data Analysis}

The data collection tools were administered to 380 students. The data were analyzed using SPPS 25 statistical software and were evaluated at .05 significance level. Descriptive statistics (mean, standard deviation, median value, minimum, maximum, number and percentile) were used for categorical and continuous variables. The relationship between the variables was analyzed using correlation analysis.

\section{Results}

Table 1. Results regarding reading comprehension skill

\begin{tabular}{lllll}
\hline Reading Comprehension Achievement Test & Mean & S.D. & Min. Score & Max. Score \\
\hline RCAT & 61.23 & 10.77 & 16 & 100 \\
\hline
\end{tabular}

Table 1 shows that the mean RCAT score is 61.23 , the standard deviation value is 10.77 , the lowest (min.) score is 16 , and the highest $(\max )$ score is 100. 
Table 2. Results regarding listening comprehension skill

\begin{tabular}{lllll}
\hline Listening Comprehension Achievement Test & Mean & S.D. & Min. Score & Max. Score \\
\hline LCAT & 60.81 & 11.77 & 11 & 96
\end{tabular}

Table 2 shows that the mean LCAT score is 60.81 , the standard deviation value is 11.77 , the lowest (min.) score is 11 , and the highest (max) score is 96.

Table 3. Results regarding creative thinking skill

\begin{tabular}{lllll}
\hline Test of Creative Thinking & Mean & S.D. & Min. Score & Max. Score \\
\hline Fluency & 29.53 & 12.71 & 2 & 76 \\
Flexibility & 190.15 & 32.72 & 0 & 402 \\
Originality & 10.04 & 4.15 & 0 & 37 \\
Creativity & 230.24 & 45.01 & 2 & 484 \\
\hline
\end{tabular}

Table 3 shows that the arithmetic mean of the fluency sub-dimension of the creative thinking test is 29.53 , the standard deviation value is 12.71 , the lowest (min) score is 2 , and the highest ( $\max )$ score is 76 . The arithmetic mean score of the flexibility sub-dimension is 190.15 , the standard deviation value is 32.72 , the lowest ( $\min$ ) score is 0 , and the highest (max) score is 402. The arithmetic mean score of the originality sub-dimension of the creative thinking test is 10.04 , the standard deviation value is 4.15 , the lowest ( $\min$ ) scores is 0 , and the highest ( $\max$ ) score is 37 . The arithmetic mean of the test is 230 , the standard deviation value is 45.01 , the lowest (min) score is 2, and the highest (max.) score is 484 .

Table 4. The relationships between reading comprehension and listening comprehension and creative thinking skill levels

$\begin{array}{lllll}\text { Reading } & \text { Listening } & & \\ \text { Comprehension } & \text { Comprehensio } & \text { Fluency } & \text { Flexibility } & \text { Originality } \\ \mathbf{n}\end{array}$

\begin{tabular}{lllllll}
\hline Listening & $\mathrm{r}$ & $.710^{* *}$ & & & \\
Comprehension & $\mathrm{p}$ & 0.001 & & & \\
Fluency & $\mathrm{r}$ & $.324^{* *}$ & $.318^{* *}$ & & \\
& $\mathrm{p}$ & 0.001 & 0.001 & & & \\
Flexibility & $\mathrm{r}$ & $.240^{* *}$ & $.262^{* *}$ & $.665^{* *}$ & & \\
& $\mathrm{p}$ & 0.001 & 0.001 & 0.001 & & \\
Originality & $\mathrm{r}$ & $.217^{* *}$ & $.259^{* *}$ & $.579^{* *}$ & $.658^{* *}$ & \\
& $\mathrm{p}$ & 0.001 & 0.001 & 0.001 & 0.001 & \\
Creativity & $\mathrm{r}$ & $.266^{* *}$ & $.286^{* *}$ & $.751^{* *}$ & $.991^{* *}$ & $.710^{* *}$ \\
& $\mathrm{p}$ & 0.001 & 0.001 & 0.001 & 0.001 & 0.001 \\
\hline
\end{tabular}

As Table 4 shows the most significant correlation is between reading comprehension and listening comprehension, and the least significant correlation is between reading comprehension and fluency, which is a sub-dimension of creativity. There is a positive, statistically significant relationship between the listening comprehension and creative thinking skill scores $(\mathrm{r}=.28, \mathrm{p}<.05)$. There is a positive and statistically highly significant relationship between reading comprehension and listening comprehension skill scores $(r=.71, p<.05)$. There is a positive significant relationship between reading comprehension and creative thinking skill skills ( $\mathrm{r}=.26, \mathrm{p}<.05)$. All of the relationships are statistically significant. 


\section{Conclusion, Discussion and Suggestions}

According to the results obtained from the practices, the participating middle school students' mean score of reading comprehension is 61.23 , and their mean score of listening comprehension is 60.81 , and they have a medium level achievement. In the relevant literature, Sert (2010), and Ünal (2006) found students' reading comprehension skill insufficient and Ateş (2008), Girgin (2012) found moderate; Çelebi (2008) and Bulut (2013) found students' listening comprehension skills moderate, Yildırım et al. (2010) found low. Both the literature and this study show that middle school students' comprehension skills are not low, albeit at an insufficient level. Researchers examining Turkish lesson curricula draw attention to the important deficiencies found in the learning outcomes. Batur and Ulutaş (2013), who examined the 2006 Turkish Language Curriculum in terms of reading skill acquisitions, stated that approximately eighteen of the fifty-one acquisitions serve the A and B levels determined by PISA, and that the high level of achievements at the lower level prevents students from reaching the next level; Güzel and Karadağ (2013) stated that not all features of learning areas are reflected in learning outcomes; Ar1 (2017) stated that there are some ambiguities in the outcomes, and the fact that the same outcome statements are distributed to different classes in different dimensions creates problems in terms of integrity and coherence; Bal (2018) states that only 14 of the 69 acquisitions for 5th graders in the 2017 Turkish Language Curriculum are related to 21 st century skills. The deficiencies seen in the programs explain some of the inadequacy in the students' comprehension skills. It seems difficult for the reader who cannot use the reading comprehension strategies to reach the deep meaning in the text (Baker \& Brown, 1980; McNamara et al., 2007; Aarnoutse et al., 2014), and for the person who has not gained the habit of reading, to achieve the expected success in reading comprehension. In the report of the Ministry of National Education (MEB) on Leisure Time and Reading Habits, it is seen that Turkey ranks low when compared to other countries in terms of reading, and that its citizens cannot acquire regular reading habits. Although almost more than $90 \%$ of our country is literate, the literacy rate is 4.5\%" (Can et al., 2010: 3).

There are many reasons for the inadequacy of the students in comprehension skills; however, the important ones are the false belief that the listening skill is acquired spontaneously, the students' lack of reading habits, the problems arising from the curriculum, the inadequacy of the textbooks and the poor socioeconomic situation of the families.

The third sub-problem of the study is "Is there a significant relationship between 7 th grade students' creative thinking skills and their reading and listening skills?" This study found a low level, positive and significant relationship between comprehension skills and creative thinking skills. Wang (2012) found a positive relationship between creative thinking, reading attitude and the time spent for reading. Palamut (2008) reported that story reading activities increased students' creativity level, Hicks (1979) and Despos (1980) found that creative thinking activities improved students' reading comprehension skills, Hizır (2014) and Yurdakal (2018) reported that creative reading activities increased students' creative thinking skills. On the other hand, Brooks (1985)found that creative thinking activities did not have any effect on reading comprehension skills. Brouillette (2012) claimed that creative drama activities positively affected students' listening and speaking skills, and according to Aldig and Arseven (2017), listening acquisition in the program improved students' creative thinking skills.

Both this study and the literature show a positive and significant relationship between reading and listening comprehension and creative thinking skills. Creativity refers to a process related to the skills required for reading. Activities such as thinking, remembering, reasoning, wondering, exploring and freedom of expression that facilitate creativity can be developed with 
reading and listening practices (Wang, 2012, p. 40). Creativity occurs in a social context, which indicates that the listening skill is necessary for creative thinking skills (Tavalin, 1995, p. 133).

Individuals who want to prepare their minds for creative endeavors should have knowledge of the field they study on, and knowledge about factors that increase or inhibit creativity and other areas (Sternberg \& Lubart, 1999, p.12; Smith et al., 2000, p. 115; Fasko, 2001, p. 3239). A creative idea emerges only when the acquired information is processed mentally and thought over a certain period of time. In this case, it is unlikely to come up with creative ideas or products without accessing information. The most effective way to reach information is to use reading and listening skills actively. Competence in these skills supports and develops students' creative thinking skills. It is necessary that students be encouraged to develop a positive attitude toward reading, listening, and writing and practice reading and writing in order to develop their creative thinking (Wang, 2012, p. 45).

\section{Recommendations}

(1) 1. In the current study, it has been determined that the reading comprehension skills of secondary school 7th grade students are not low, but they are not at a sufficient level. Research can be conducted on the causes of deficiencies in students' comprehension skills.

(2) 2. Studies can be conducted on what can be done to increase the success of students' reading and listening comprehension.

(3) 3. Teachers can increase the number of activities they do to improve students' reading and listening comprehension skills.

(4) 4. In future research, the relationship between students' creative thinking skills and other language skills can be examined.

\section{Acknowledgements}

This article was created from the doctoral thesis titled "Examination of the Relationship Between Critical and Creative Thinking Skills and Comprehension Skills of Secondary School Students". I would like to thank the Scientific and Technological Research Council of Turkey (TÜBİTAK) Scientist Support Department for financially supporting me during my doctoral education within the scope of the 2211.

\section{References}

Aarnoutse, C., Brand-Gruwel S. \& Oduber, R. (2014). Improving reading comprehension strategies through listening. Educational Studies, 23(2), 209-227. https:// doi.org/10.1080/030556997023020.

Ahioğlu- Lindberg, E. N. (2011). Piaget ve ergenlikte bilişsel gelişim [Piaget and cognitive development in adolescence ].Kastamonu Journal of Education, 19(1), 1-10.

Akar, C. (2007). Illköğretim öğrencilerinde eleştirel düşünme düzeyleri [Critical thinking levels in primary school students] (Doctoral thesis). Gazi University, Ankara.

Aldig, E. \& Arseven, A. (2017). The contribution of learning outcomes for listening to creative thinking skills. Journal of Education and Learning, 6(3), 41-53. http://doi.org/10.5539/jel.v6n3p41

Arı, G. (2017). Evaluation of reading achievements in Turkish lesson curriculum (secondary school). Journal of Mother Tongue Education, 5(4), 685-703. 
Aslan, E. (2001). Torrance Yaratıcı Düşünme Testi'nin Türkçe versiyonu [Turkish version of Torrance Creative Thinking Test]. Journal of Educational Sciences, 14, 19-40.

Ateş, M. (2008). Illköğretim ikinci kademe öğrencilerinin okuduğunu anlama düzeyleri ile türkçe dersine karşı tutumları ve akademik başarıları arasındaki ilişki [The relationship between primary education second grade students' reading comprehension levels and their attitudes towards Turkish lesson and their academic achievement] (Doctoral thesis). Selçuk University, Konya.

Baker, L. \& Brown, Ann L. (1980). Metacognitive skills and reading. P. David Pearson, Rebecca Bar, Michael L. Kamil, Peter Mosenthal (Eds.), Handbook of reading research (353-394). New York: Lawrence Erlbaum Associates. https://doi.org/10.4324/9781315200651

Bal, M. (2018). Türkçe dersinin 21. yüzyıl becerileri açısından incelenmesi [Examination of Turkish lesson in terms of 21 st century skills].Turkish Studies, 13(4), 49-64. http://dx.doi.org/10.7827/TurkishStudies.12922

Batur, Z. \& Ulutaş, M. (2013). PISA ile Türkçe öğretim programındaki okuduğunu anlama kazanımlarının örtüşme düzeylerinin incelenmesi [Examination of the overlap levels of the reading comprehension achievements in the Turkish curriculum with PISA]. The Journal of Academic Social Science, 6(2), 1549-1563.

Brooks, J.A. (1985). The effect of creative thinking instruction on seventh and eighth graders and the relationship of creative thinking to iq and reading achievement (Education and Masters and Human Developmant Master's). State University of New York, New York.

Brouillette, L. (2012). Advancing the speaking and listening skills of K-2 English language learners through creative drama. TESOL Journal, 3(1), 138145. https://doi.org/10.1002/tesj.8

Bulut, B. (2013). Etkin dinleme ĕgitiminin dinlediğini anlama, okuduğunu anlama ve kelime hazinesi üzerine etkisi [The effect of active listening education on listening comprehension, reading comprehension and vocabulary]. (Master's thesis). Adnan Menderes University, Aydın.

Büyüköztürk, Ş., Kılıç Çakmak, E., Akgün, Ö. A., Karadeniz, Ş. \& Demirel, F. (2013). Bilimsel araştırma yöntemleri[Scientific research methods].Ankara: Pegem publishing.

Cropley, A. J., (2006). Creativity: Social Approach. Reoper Review, 28(3), 125-130. https://doi.org/10.1080/02783190609554351

Can, R., Türkyılmaz, M. \& Karadewniz, A. (2010). Ergenlik dönemi öğrencilerinin okuma alışkanlıkları[Reading habits of adolescent students]. Journal of Ahi Evran University Faculty of Education, 11(3), 1-21.

Çam, B. (2006). Illköğretim öğrencilerinin görsel okuma düzeyleri ile okuduğunu anlama, eleştirel okuma ve Türkçe dersi akademik başarıları arasındaki ilişki[The relationship between primary school students' visual reading levels and their reading comprehension, critical reading and Turkish course academic achievements] (Master's thesis). Eskişehir Osmangazi University, Eskişehir.

Çam, O. \& Öztürk Turgut, E. (2015). Yaratıcılık [Creativity].Ege University Journal of Nursing Faculty, 31(2), 78-85.

Çelebi, H. M. (2008). Illköğretim 6, 7 ve 8. sinıf öğrencilerinin olay ve düşünce yazılarına göre dinleme becerilerinin degerlendirilmesi [Evaluation of the listening skills of 6th, 7th and 8th grade students according to the events and thoughts] (Muğla Örneği) (Master thesis). Muğla Sitkı Koçman University, Muğla.

Davarc1, N. (2013). Illköğretim 8. sinıf ögrencilerinin kitap okuma alışkanlı̆̆ ile bilgisayarinternet kullanımı arasındaki ilişkinin değerlendirilmesi [Evaluation of the relationship between primary school 8th grade students' reading habits and computer-internet use] (Master thesis). Çukurova University, Adana. 
Demirel, Ö. \& Şahinel, M. (2006). Türkçe ögrretimi [Turkish teaching]. Ankara: Pegem A.

Despos, C. M. (1980). A study of the effect of selected teaching strategies on creative thinking ability and reading comprehension (Education and Human Development Theses). State Unversity of New York, New York.

Fasko, D. (2001). Education and creativity. Creativity Research Journal, 13(3-4), 317-327. https://doi.org/10.1207/S15326934CRJ1334_09

Fisher, R. \& Williams, M. (2004). Unlocking creavity. David Fulton Publishers.

Gardner, H. (1997). The creators' patterns. Publised in Margaret A. Boden (Eds.), Dimensions of Creativity. The MIT Press.143-158.

Girgin, Y. (2012). İlkögrretim 8. sinıf Türkçe ders kitaplarındaki metinlerde kavram haritası kullanımının ögrencilerin okuduğunu anlama becerileri üzerine etkisi [The effect of using concept maps in the texts in primary school 8th grade Turkish textbooks on students' reading comprehension skills](Doctoral thesis). Atatürk University, Erzurum.

Guilford, J. P. (1950). Creativity. American Psychologist, 5(9), 444-454.

Gül, F. \& Soysal, B. (2009). Dil ve düşünce ilişkisi üzerine[On the relationship between language and thought]. Social Sciences Research Journal, 13, 65-76.

Güzel, A. \& Karadă̆, Ö. (2013). Anlama becerileri açısından Türkçe dersi öğretim programı $(6,7,8$. sınıflar)'na eleştirel bir bakış [A critical look at the Turkish course curriculum (6th, 7th, 8th grades) in terms of comprehension skills]. Journal of Mother Tongue Education, 1(1), 45-52. https://doi.org/10.16916/aded.81751

Hızır, B. (2014). Illkögretimde yaratıcı okumanın yaratıcı düşünme becerilerine etkisi [The effect of creative reading on creative thinking skills in primary education] (Master thesis). Muğla Sitkı Koçman University, Muğla.

Hicks, C. G. (1979). The development of creative thinking and its relationship to iq and reading achievement (Education and Human Development Master's Theses), State University of New York.

Karasar, N. (2019). Bilimsel araştırma yöntemi [Scientific research method]. Ankara: Nobel.

McNamara, D. S., O'Reilly, T., Rowe, M., Boonthum, C. \& Levinstein, I. (2007). START: a web-based tutor that teaches self-explanation and metacognitive reading strategies. Danielle S. McNamara Reading (Eds.), Reading comprehension strategies theories, interventions, and technologies (397-421). New York: Lawrence Erlbaum Associates.

Öz, F. (2011). Uygulamalı Türkçe ögrretimi[Applied Turkish teaching]. Ankara: Anı.

Palamut, İ. (2008). Hikâye okumanın ilkögrretim öğrencilerinin yaratıcılık düzeylerine ve akademik bassarllarına etkisi[The effect of story reading on the creativity and academic success of primary school students] (Master thesis). Dokuz Eylül University, İzmir.

Sert, A. (2010). İlköğretim 6. sınıf öğrencilerinin okuduğunu anlama becerilerinin bazı değişkenler açısından incelenmesi[Examination of primary school 6th grade students' reading comprehension skills in terms of some variables] (Master thesis). Selçuk University, Konya.

Smith, D. K., Paradice, D. B. \& Smith, S. M. (2000). Prepare Your Mind for Creativity. Communications of the ACM, 43(7), 110-116. https://doi.org/10.1145/341852.341870

Söylemez, Y. (2016). İçerik analizi: eleştirel düşünme [Content analysis: critical thinking].EKEV Academy Journal, 20(66), 671-696.

Seidel, S., Müller-Wienbergen, F., \& Becker, J. (2010). The concept of creativity in the information systems discipline: Past, present, and prospects. Communications of the Association for Information Systems, 27(1), 217-242. https://doi.org/17705/1CAIS.02714

Sternberg, R. J \& Lubart, T. I. (1999). The concept of creativity: prospects and paradigms. Published in Robert Sternberg (Eds.), Handbook of creativity. Cambridge University Press. 
Tavalin, F. (1995). Context for creativity: listening to voices. allowing a pause. The Journal of Creative Behavior, 29(2), 133-142. 10.1002/j.2162-6057.1995.tb00741.x

Temur, T. (2010). Dinleme metinlerinden önce ve sonra sorulan soruların üniversite öğrencilerinin dinlediğini anlama beceri düzeyine etkisi [The effect of questions asked before and after the listening texts on university students' listening comprehension skill level]. Selcuk University Ahmet Keleşoğlu Faculty of Education Journal, 29, 303-319.

Ungan, S. (2007). Dinleme [Listening]. (A. Kırkkılıç \& H. Akyol). Illköğretimde Türkçe ögretimi [Turkish teaching in primary education] (135-160). Ankara: PegemA publishing.

Ünal, M. (2012). 6. sinıf öğrencilerinin okuma tutumlarının okuduğunu anlamaya olanetkisi[The effect of 6th grade students' reading attitudes on reading comprehension] (Master thesis). Ondokuz Mayıs University, Samsun.

Wallas, G. (1926). The art of thought. London: Jonathan Cape.

Wang, A. Y. (2012). Exploring the relationship of creative thinking to reading and writing. Thinking Skills and Creativity, 7(1), 38-47. https://doi.org/10.1016/j.tsc.2011.09.001

Wojciehowski, M. \& Ernst, J. (2018). Creative by nature: investigating the impact of nature preschools on young children's creative thinking. International Journal of Early Childhood Environmental Education, 6(1), 3-20.Wood, C. L. \& Gabas, C. M. (2017). Young Spanish-English speaking children's reading attitudes in relation to language skills. Educational Research, 59(4), 408-425. https://doi.org/10. 1080/00131881. 2017. $\underline{1373028}$

Yıldırım, K., Yıldız, M., Ateş, S. \& Rasinski,T. (2010). İlköğretim beşinci sınıf Türk öğrencilerin metin türlerine göre okuduğunu ve dinlediğini anlama düzeyleri [Level of reading and listening comprehension of fifth grade Turkish students in primary education].Educational Sciences in Theory and Practice /Educational Sciences: Theory \& Practice, 10(3), 5-37.

Yurdakal, İ. H. (2018). Yaratıcı okuma çalışmalarının ilkokul 4. sınıfta yaratıcı okuma ve yaratıc düşünme becerilerini geliştirmeye etkisi [The effect of creative reading activities on developing creative reading and creative thinking skills in primary school 4th grade] (Doctoral thesis). Pamukkale University, Pamukkale. 